\title{
Forward Exchange Rates in Efficient Markets: The Effects of News and Changes in Monetary Policy Regimes
}

\author{
Mack Ott and Paul T. W. M. Veugelers
}

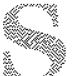
INCE the late $1970 \mathrm{~s}$, theoretical explanations of exchange rate detemination have emphasized the asset approach rather than the expenditure approach.' Most of the empirical research applying the asset models of exchange mate defemination also subsume the efficient market hypothesis. In this article, we lest three efficient market hypotheses bearing on forward exchange rates: First, are forwand rates unbased forecasts of future spot exchange rates? Second, does "news" - in particular unanticipated changes in nominal or real interest differentials - explain for-

Mack Ott is a senior economist at the Federal Reserve Bank of St. Louis and Paul T.W. M. Veugelers, formerly a professor in the Department of Monetary Economics, Erasmus University, is a private consultant in the Netherlands. This article is the result of research undertaken in 1985 during an exchange of visits - Mr. Veugelers to this Bank and Mr. Ot to Erasmus University. The authors acknowledge the research assistance of James C. Poletti and the helpful comments of Clemens Kool.

One rationale for this shift is the observation that the interest rate parity (IRP) postulate of the asset view has held up substantially better than the purchasing power parity (PPP) postulate of the expenditure view; see Mussa (1979) and Frenkel (1981b). The former refers to the equality of asset yelds across currencies, while the latser fefers to the equality of purchasing power across currencies. PPP frequently, and for protracted periods, has been violated by exchange rates; see Frenkel (1981b). Thus, analysts have been faced with either modifying the PPP assumption and diluting its relevance, or accepting the evidence and developing theories to explain it. Indeed, some authors, Bomhoff and Korteweg (1983) and Darby (1981), argue that changing real exchange rates vitiate the relevance of $P P P$. ward rate forecast errors? Third, are forward rate forecast errors affected by change in the U.S. monetary policy regime? These hypotheses are tested by examining the forecast errors the difference betweon the forward rate and the subsequently observed spot rate for the U.S. dollar forward rate against the currencies of eight industrialized countries over the latest floating-rate era $(1973-85)$.

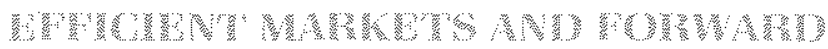

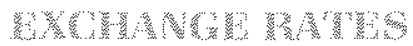

The forward exchange rate in an efficient market reflects all the information possessed by individuals active in that market. Thus, in an open market, the forward rate should be an unbiased predictor of the future spot ate." Hence, a regression of the observed spot rate at lime $t$ on the forward rate at time $t-1$ where exchange rates are measured by natural logarithms of the dollar prices of foreign exchange,

(1) $s_{1}=a+b s_{1-1}+e_{1}$,

should result in an estimated constant hot significantly different from zero, an estimated coefficient on

\footnotetext{
see Dombusch (1976), Mussa (1979). Frenkel (1981a), Bomhoff and Korteweg (1983) and Edwards (1983b).
} 
the forward bate not significantly different from 1.0 . and serially uncorrelated erors $\left(e_{4}\right)$ :

\section{Jen}

The empirical finding of a significant intercept has been sufficiently frequent in recent reseach that it is no longer interpreted as a departure from market efficiency. The question, then, is, what does lhe significant intercept represent?

The current view is that the intercept represents a return to speculation." For example, if real interest rates on U.S. securities are higher than those on foreign securities, investors will shift their portotios towand the higher-yielding securities denominated in U.S. currency; if these investors are risk-averse to unforeseen changes in curtency values, they can bedge by selling the higher-yielding U.S. currency forward and buying thei" own currency forward. By IRP, the resulting upward pressure on the forward rate must just offset the higher yield obtained on the U.S. securities." Thus, the forward rate in equation 1 , in such cases, would overestimate the future spot rate so that the estimated interept would be negative. Conversely, a higher rate on non-U.S. securities, by the same logic, would imply a positive intercept.

\footnotetext{
${ }^{3}$ These propositions about the forward exchange rate have not been supported by recent empirical work. For example, Hansen and Hodrick (1980) find significant evidence of risk premia and explanatory power in lagged errors in both the 1920 s and 1970 s in one and three-month forward markets. Baillie, Lippens and McMahon (1983), using a time series model on weekly data reject the hypothesis that the forward rate is an unbiased predictor of the future spot rate in weekly data. Fama (1984) argues that the risk premium explains much of the error in the forward rate's forecasts and finds that the risk premium and expected future spot rate are negatively correlated. Jacobs (1982) argued that the forward rate is an imperfect proxy for the expected rate and constructs a time series proxy for the expected rate. Unlike Fama, however, Jacobs found informaton in the past variables, that is, information not included in the efficiently constructed forward rate at fime $\mathbf{t}-1$. Jacobs' emphasis on omitted information is analogous to the decomposition suggested by Frenkel (1981a) and elaborated in Isard (1983) and Edwards (1983a, 1983b). Edwards (1983b) finds that market efficiency is not rejected in three out of four currencies in his study once news is included.

"Fama (1984) and Hodrick and Srivastava (1985). Hodrick and Hansen (1983) find that significant premia are both common and time varying. Frenkel (1981a) finds that news explains some of the risk premium while Edwards ( $1983 \mathrm{~b}$ ) finds that the combination of news and a system estimation technique eliminates the significant intercept.

sinvestors are concerned about after-tax real rates of return: throughout this article we ignore the possibility that long-run real interest differentials may persist due to different tax rates on interest and investment income. Since our tests are on the effects of unanticipated changes in interest differentials, this possibility does not affect our results.
}

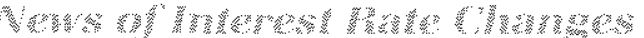

Frenkel (1981a) argues that changes in expectations between the lime that the forward rate prediction is made and the spot rate is observed explain the forward erros. These changes in expectations, which he calls news, are based on infomation revealed after the forwand contracts are made but before the spot rates are realized. Thus, unanticipated changes in interest late differentials between time $t-1$ and $t, \ldots$ one example of news - explain part of the residual between the forward rate forecast $f_{1-1}$ and the realized spot rate $\mathrm{s}_{\mathrm{r}}$. Incorporating this modification into equation 1 yields

(2) $s_{1}=a+b f_{i-1}+c\left(i-i^{+}\right)_{1}-E_{i-1}\left(i-i^{*} l_{1}\right)+e_{1}^{\prime}$

where $i$ is an interest rate of the same term as the forward rate with asterisks indicating non-U.S. variables linterest rates are not in logsl. Once again, riskneutrality and efficient makets would imply an insignificant intercept and a slope coefficient of unity; the sign of the coefficient on the news variable, however, would depend upon whether the rise in the interest diferental were due to a relative rise in U.S. inflation - in which case if would be positive - or a relative rise in U.S. real interest ates - in which case it would be negative."

Frenkel's proxy for the expected interest rate differential was obtained from a regression of the interest differential on its own lagged vatues and the lagged forwand exchange rate. Estimating this model over 1973-79 for the pound sterling, deutschemark and franc, he found the intercept to be insignificant and the coefficient of the lagged forward rale not significantly different from one; these findings are consistent with the eflicient market hypothesis, Moreover, the coefficients on the news variable - the unanticipated interest rate change - were positive, which he interpreted as primarily reflecting the relatively high and rising U.S. expected inflation rate during this period.

\section{W

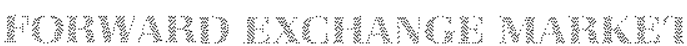

An important insight of the asset-market approach to exchange mate determination is the emphasis on expectations. Asset prices are much more dependent

An increase in the expected inflation rate differential implies that, in the future, the dollar price of foreign currency will rise faster, and fewer dollars will be demanded because of their higher holding cost hence, $s$, would rise. An increase in the U.S. real interest rate relative to foreign rates would increase the value of the dollar: hence, $s_{i}$ would fall. 
than curent goods prices on the anticipated course of future events. Consequently, the role of news is most aptly captured in the change of expectations, not the error between the expected and realized yield differentials.

By an application of IRP and the efficient forward market hypothesis for loreign exchange, we can obtain an alternative form of the news equation 2 estimated by Frenkel. The alternative model takes the form isee shaded insert on the next page:

(3) $s_{1}-f_{1-1}=\alpha+\beta \Delta f_{1}+\omega_{1}$

This model has the advantage of using a marketimplied interest differential as well as directly embodying the change in expectatsons rather than the empirically derived, expectation error proxy used by Frenkel.

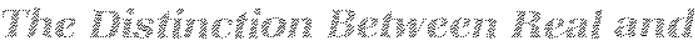

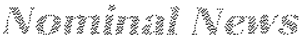

Frenkel claimed that the positive coefficient on the interest rate news he found during 1973-79 reflected the felatively high and rising U.S. inflation rate during this period. Since the U.S. inflation rate has fallen both absolutely and relative to other nations in the years since 1979 , the estimated coefficient on the expected nominal interest differential should be unstable over the full period 1973-85. One way to deal with this problem is to break the period into smaller units, each of which have uniform relative U.S. inflation rates. We, instead, separate the real and inflation components of the nominal news variable. That is, we will view the change in the nominal interest differential as the sum of a change in the expected real yield differential and the change in the expected inflation differential. These components of the news should have different effects on the forward fate errors.

A rise in the real vield on investments in one country relative to those elsewhere, in the absence of capital restrictions, will cause an inmedale appreciation in its exchange rate and result in a negalive eror in equation 3 . Such appreciations are transitory because captal inflows will boing down the intially higher yidds, while the concomilat outlows tase the yields elsewhere, unil equality of yieds is restomed Consequently, the very rise in the relative yield that causes a

7 See Dombusch (1976). Isard (1983), and Edwards (1983a). Nonetheless, the existence of risk premia implies that interest differences. have persisted for some time in open capital markess; see Fama (1984). Hodrick and Hansen (1983) find these fisk premia to be monconstant and that their time variation is not summarized by mominal interest rate movements. currency to appreciate also creales the anticipation of its subsequent depreciation as yield differences go to zero.

In contrast, an increase in the expected inflation differential primarily alles the rate of depreciation of the exchange rate by changing its PPP level; a rise in the inflation differential causes the exchange rate to rise faster over time by the amount of the inflation increase. The depreciation of the spot rate also will reflect the perceived increase in the holding costs of the country's currency which reduces the quantity demanded.

Thus, express the nominal news as the sum of its real and inflation components.

(4) $\Delta \mathrm{f}_{\mathrm{t}}=\Delta\left(\mathrm{r}_{1}-\mathrm{r}_{1}^{* *}+\Delta\left(\pi-\pi_{1}^{*}\right)\right.$

where $r_{i}=$ expected real interest rate, and

$\pi_{1}=$ expected inflation rate.

Then, substitule the right $\mathrm{mand}$-side of equation 4 into equation 3 , to obtain

(5) $\left.s_{1}-r_{1-1}=\alpha+\beta_{1} \Delta \mid r_{1}-r_{1}^{*}\right)+\beta_{2} \Delta\left(\pi_{1}-\pi_{1}^{*}\right)+\varepsilon_{1}$.

In equation $5, \alpha$ is non-zero in the presence of a risk premium, $\beta_{*}$ is negative isince an unanticipated felative rise in I $S$, real rates lowers $s_{3}$ implying $s_{1}-f_{1-3}<$

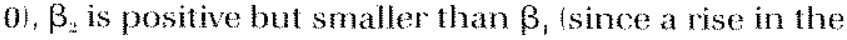
relative U.S. intlation rate will cause a change in the rate of depreciation of the dollar, and, through decreased demands for transacton balances, some decline in its level, and $E_{1}$ is a sertally uncorrelated disturbance term.

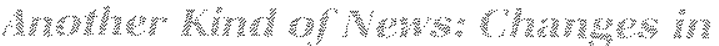

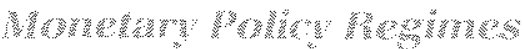

The estimated parameters of an economic velation reflect the pereeived policy stance of the govemment and monetary authotities. Thus, as Lueas $(1974)$ a ${ }^{-}$ gued, changes in policy, either broad goals such as the desired inflation rate or harrower ones such as lhe method in which the policy is implemented, nay alle" the public's response to prices and otherinformation."

We abstract from changes in the long-run real exchange rate in this analysis. That is, different rates of capital or human capital investment will cause different rates of productivity growth, or resource price changes that can alter the real exchange rate; see Darby (1980), Bomhoff and Korfeweg (1983). Also, a reduction in the security of property rights can make investment in one currency less attractive than investments in other currencies, depreciating the currency and raising its real yields; see Dooley and isard (1980). An apt application of the Dooley-Isard hypothesis may be the chance in the Fronch government in 1981, which was followed by significant nationalizations - especially in the banking sector. In our andysis. the only struetural change considered is the U.S. monetary policy regime. 


\section{Forward Exchange Rate Errors, Efficient Markets and the News: the Role of the Forward Premium}

In its strong form, the efficient market hypothesis implies that the intercept in equation 1 will be zero and the coefficient of the lagged forwand rate will be unity consequently, the error term, $e_{\varepsilon}$ is simply the error of the forward rate's forecast of the spot vate,

$(2.1) s_{i}-f_{1-1}=e_{1}$

Frenkel's insight conceming the role of news is to argue that this ertor is due to information revealed affer $t-1$ but before $t$ which alters expectations and hence, $s$.

- . current exchange rates already refect current expectations about the future, while changes in the current exchange rate reflect primarily changes in these expectations which by definition arise from new information:

Frenkel s specification equation 2 employs the dif ference between the realzed interest differential and the expected differential, however his angument implies that the news variable should be the change in the expected different al between $1-1$ and 1 That is

Frenkel ( 1981 b) po $700-701$, emphasis added: Frenkel notes (see footnote 31, p. 701 ) that Gustav Cassel, "the most recog. nized proponent of the purchasing power parity doctrine" also recognized this forward-looking aspect

The international valuation of the currency will, then generally show a tendency to anticipate events, so to speak, and become more an expression of the internal value that the currency is expected to possess in a few months, or per haps in a year's time (Cassel 1930 , pp. $149-50$ ).

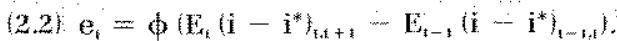

IRP implies that the annualized one-month forward pamium,

$(2.3) . \mathrm{p}_{\mathrm{z}}=12\left(\mathrm{f}-\mathrm{s}_{\mathrm{k}}\right)$

is equal to the interest differental expected to prevail during $t$ through $t+1$

$24 \mathrm{p}_{\mathrm{r}}=\mathrm{E}_{\mathrm{l}} \mathrm{a}-\mathrm{p}_{\mathrm{L}}+\mathrm{n}$

where the term to maturity of the interest rates is equal to the holding penod in fp If this equality did not hold, riskless oppontunities for profitable arbitrage would exist: Thus, substituting the relevant forward prema from equation 24 for the expected mtenest diffenentials in equation 2,2 and then $s u b$ stituting this expression for the erron term in equation 21 , we obtain

$(25) \mathrm{s}-1-\phi(\Delta \mathrm{fp})$

which can be written an an estimable form as $\left(3 s_{1}-\mathrm{f}_{1-\mathrm{r}}=\alpha+\beta \Delta \mathrm{p}_{\mathrm{q}}+\omega_{\mathrm{l}}\right.$

This is known as the covered arbitrage condition, For example, if the $f \mathrm{p}_{\mathrm{r}}<\left(i_{\mathrm{us}}-i_{\mathrm{u} k}^{*}\right)$, an investor could sell pounds and buy dollars at time 1 , use the proceeds to buy a U.S security; by buying forward pounds at the investor removes any exchange rate risk and obtains a higher yield than he would have in U.K securites. Since this yeld differental is riskless, arbitrage should drive it to zero and in the process, ensure the equality shown in equation 2.4. For a fuller discussion and many instructive examples, see Wood and Wood (1985), pp. 378ff
Therefore, regression estimates of equations 2,3 or 5 may be sensitive to changes in policy goals and regimes.

In particular, the hypotheses for real and inflation news summarized above are dependent on the monetary policy regime. For example, when the monetary allhority targets monelay growth, inferesl fales will be detemined by the private and public demand for loanable funds; unforesen changes in that demand will cause changes in interest rates. Interest mates also will reflect private expectations aboul inflation. In such a monetary policy regime, the Fisher hypothesis holds, so that real inferest rates are simply the difference between nominal interest ates and anticipated indmion; consequently equation 4 holds, while gqua tion 5 follows as an implication of equations 3 and 4 ."

In contrast, consider a monetary policy regime of

\footnotetext{
However, a critical caveat in evaluating equation 5 (or $5^{\prime}$, see below) is Fama's assertion that, when complete PPP does not hold, uncertainty and differential tastes combine "to strip the Fisher equation of its meaning" (1984, p. 323).
} 
targeting interest rates. ${ }^{10}$ Under such a policy stance. movements in interest rates are, to some extent, policy determined in the short run since changes in the nominal interest rate induce ofsetting changes in the money supply through a policy-reaction feedback.

Consequently, changes in interest rates under a regine of targeting interest rates comvey different information than do interest rate changes under a regime of targeting monetary aggregates. A real interest differential under interest-rate targeting cannot be closed by capital flows alone if the monetary authority chooses to maintain a particular nominal target rafe which maintains the differential. Over time, an interest rate target below the maket rate will increase the inflation differental. The adjustment process then depends totally upon the relative inflation rates to restore PPP. And, again, the risk premium embodied in the intercept should be smaler during an interest-rate regime due to the reduced shortmun, interest-rate uncertainty.

This policy regime hypothesis can be tested by an $\mathrm{F}-$ lest on the restriction implicit in both equation 3 and 5 that the coefficients - $\alpha, \beta, \beta_{1}, \beta_{2}-$ are stable over changes in monetary policy regimes. The restriction is tested by adding intercept and slope dummy variables to get equations $3^{\prime}$ and $5^{\prime}$, computing the F-statistic on the change in the residuals between the estimates of the restricted and unrestricted equations:

$$
\begin{aligned}
& \left(3^{3}\right) s_{1} \cdots r_{1,1}=\alpha_{t 1}+\alpha_{1,1} \mathrm{D}+\beta_{t 1} \Delta \mathrm{fp}_{1}+\beta_{t, 2} \mathrm{D} \Delta \mathrm{fp}_{1}+\omega_{1}^{\prime} \\
& \left(5^{\prime}\right) s_{1}=r_{1-1}=\alpha_{11}+\alpha_{11} \mathrm{D}+\beta_{1} \Delta\left(r_{1}^{*}-r_{1}^{*}\right)+\beta_{13} \mathrm{D} \Delta\left(\mathrm{r}_{1}-\mathrm{r}_{1}^{*}\right) \\
& +\beta_{\underline{x}} \Delta\left(\pi_{1}-\pi_{1}^{*}\right)+\beta_{2}, \mathrm{D} \Delta\left(\pi_{1}-\pi_{1}^{*}\right)+\varepsilon^{\prime}, \\
& \text { where } \mathrm{D}= \begin{cases}1 & \text { if October } 1979 \leq \mathrm{t} \leq \text { September } 1982 \\
0 & \text { otherwise. }\end{cases}
\end{aligned}
$$

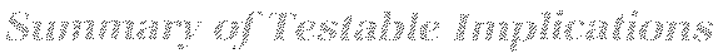

The implications of the analysis in equations $3^{\prime}$ and 5 'are worth summarizing before reporting the estimation results. First, news about the real interest differ-

\footnotetext{
10. Ony two U.S. monetary policy regimes are distinguished in this study - the October 1979-September 1982 period and the remaining period before and after. Implicitly, this assumes that both the pre-October- 1979 and the post-September-1982 periods are based on intezest-rate targeting procedures; support for this characterizaton of these two periods is offered in Gilbert (1985), Kaufman (1982) and Rasche (1985). The toreign monetary policy stance might also be argued to be relevant; white this is a possibility for a refinement on the estimates reported in this study, there do not appear to have been substantial changes during the period $1974-83$ in six of the eight countries. The policy procedures of six of the eight non-U.S. countries (excluding Italy and Netherlands) are reviewed in Johnson (1983).
}

ential causes negative forecast errors, $s_{z}-f_{1-z}$ while changes in the inflation differential cause positive forecast errors. If there are periods dominated by relative volatility in inflation and other periods dominated by real yield volatility, then equation 3 , which restricts the coefficients to equality, should be rejected by an F-test in comparison with equation 5 which does not restrict these coefficients to equality.

Second, the theory underlying equation 5 implies that news about the expected inflation differential will cause forecast errors, $s_{z}-f_{t-1}$, whose magnitude depends on the sensitivity of money demand to changes in the inflation rate. The coefficient should have the same sign as the change in the inflation differential. Given the shortness of the observation period - one month - the regression coefficient $\beta_{2}$ in equation 5 should be positive but may not be significant.

Third, since the interest rates (hence, forward prem mia) are assumed to be determined without a monetary policy eaction function in the analysis represented in equation 5, monetary policy based on interest-rate targets affects these hypotheses. If the monetary policy regime affects the market valuations, i.e. spot and forward exchange rates, hence forwardrate forecast errors, then the restrictions in equation 5 which are removed in equation : $5^{\prime}$ will be rejected by an F-test on the improved fit of equation 5 ' relative to equation 5 .

Fourth, since it is well known that the variances of U.S. interest rates, both nominal and real, have been highed during monetary target regimes than altemative regimes, there is a greater likelihood of misforecasting interest rates under a monetary target rem gime. "The risk premium measured by the intercept, which primarily is determined by this risk, should be negative, larger and more significant during periods of monetary lapgeting than during periods of interestrate targeting. This hypothesis can be tested by the significance of the intercepl's dummy varable in equations $3^{\prime}$ or $5^{\prime}$.

Finally, under the efficient market hypothesis enbodied in equations $3,5,3^{\prime}$ and $5^{\prime}$, the error terms should be serially uncorrelated. Correlation in the disturbance term implies incomplete use of past information and failure to exhaust profit opportunities. Alternatively, if markess are elficient, serially correlated residuals imply a misspecification of the estimating equation.

\footnotetext{
"See Roley (1983) and Rasche (1985)
} 


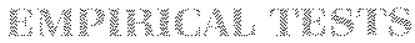

The models specified in equations $1,3,5,3^{\prime}$ and $5^{\prime}$ wore estinated using monthy data from october 1973 through whe 1985, using the U. S. dolar spot and onemonth-forvard prices of the currencies of Canada. France, Germany, Italy, Japan, the Nethertands, Switaeland and the United Kingdom. The lests are nesled in that equation 3 is obtained from equation 1 by impostion of the effecient market hypothesis. fquafion 1 also conlatins both the restriction to suppress the real interest rate vs. inflation rate decomposition and the restriction to suppress the effects of changing monetay policy regimes on the regression coetficients' values. We first test the simple efficient maket hypothesis by estimaling equation 1. Next, we estimate the simple news model with the change in the nominal fow ward premium, equation 3. This model contains both the nominal news and the policy regine restrictions above. We can then test these restrictions by estimating 5', which is unces ricted and comparing it through F-tests with equations 5 and $3^{\prime}$. F-tests on equation $5^{\prime}$ vs. equation 5 and $5^{\prime}$ vs. $3^{\prime}$ determine, respectively, whether the policy regime or nominal forward preminm restrictions can be rejected.

\section{Mas}

The spot and 30-day for ward exchange rates used in the estimates are New York opening market 110 a.m. midpoints for the last business day of the month as compled by the Bank of America. The change in the reat interest diferential was obtained from the change in the forward premium: First, the forward premium was converted to an annualized rate; the change in this annualized foward premium is the news - that is, the change in the expected nominal interest diferential. Second, an expected annualized inflation rate for the one-month horizon was computed for each country from its monhly CPI sevies." The change in the differential, U.S, minus foreign inflation, is the change in the mathation differential used in estimating equations 5 and $5^{\prime}$. The change in the real interest diferential is then the change in the annualized, nominal, one-month-foward premium minus the change in the expected inflation differential.

\footnotetext{
:Clemens Kool of Erasmus University computed this series using a mutti-state Kalman fitter. A simple Kalman filter is a forecasting method based on assumptions about the forecasted variable's refation to current and lagged data on itself and or other series. A muiti-state Kaman filter allows this relation to vary according to a feedback or adaptive error loop; the multi-state modifier refers to the alternative sets of assumed weights. A concise description and illustrative example are contained in the statistical appendix to Bomhot and Korteweg (1983).
}

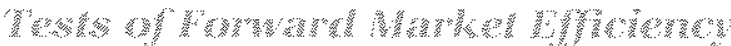

Table 1 repors the resuls of estimating equaton 1 dung the full sample period, October 1973 through June 1985 . For six of the eight currencies considered, market efficiency is not rejected; for Japan and swizerland, however, the market affciency hypothesis is rejected at the 5 percent level. For all eight, the Durbin-Watson statistic indicates that hypothesis of serally uncorrelated disturbances is not rejected. Thus, except for Japan and Swizerland, the results in table 1 indicate that the news model specified in equation 3 is an appropriate empirical model.

For Japan and Switzerland, equation 1 was reestimated by subperods before, during and since the U.S. monelary aggregate larget regime of Oclober 1979 through september 1982 . For each country the hypothesis of serially uncorrelated residuals was not rejected in any subperiod. For each of the subperiods, the efficient market bypotheses beangs on the coefficients for swizerland were not rejected. Fot Japan the earlien two subperiod estimates do not reject makef efficiency, bul the recent subperiod rejects markel officiency both in tems of a significant intercept and the deviation from unity of the lagged forward rale coefficient. is

Consequenty, for nether Switzerand not Japan is the estimation of equation 3 justified since equation 3 is derived from equation 1 assuming a unit coefficient on $f_{1-1}$. Yet, equation $3^{\prime}$ or equation 5' may be justified for switzerland since the dummy variables can accoun for the nonstable coefficient. For Japan, the calure of the effcient market hypothesis in the has subperiod is not offset by any of our variables, and in consistent with this filure that Japan rejects each of the specifications equations $3^{\prime}, 5$ and $5^{\prime}$ as reported in lables 2 and 3.

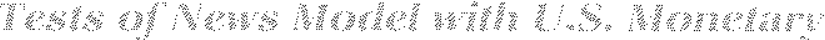

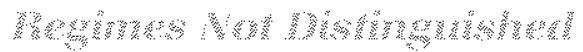

Table 2 reports the results of estimating equation 3 , the news model with the change in the nominal forward premium, over the full period, October $1973-$ June 1985. In shap contrast to the results in hble 1 , which support this specification, the estimates uniformly reject this model: no coefficient is significant at

\footnotetext{
The October 1982 - June 1985 estimates for Japan are very curious. The estimated intercept is huge in comparison with the eartierperiod Japanese estimates, the Swiss estimates or any of the estimates in table 1 :

$$
\alpha=-1.192 \text { (s.e. }=0.548 \text { ), } \beta=0.783 \text { (s.e. } \% 0.100 \text { ). }
$$
}




\begin{aligned}$P_{3} \\$\hline\end{aligned}

Standard errors of estimated coeficients appear in parentheses asterisks indicate rejection at 5 percent level of individual efficient market hypotheses intercept is zero, slopocoeficient $=10$.

Fost of jont effictent manket hypothesis that intercept is zero and slope coeffcient is unity; asterisk indicates relection at 5 percent level.

ary reasonable confolence level and the adiusted $\mathrm{H}^{2}$ is negative for six of the eight curentes lested. Consistent with the effeien market hypothesis, however: the hypothesis of seraly uncorelated disturbnes is not rejected. Nonetheless, the results recuire an investigathon of alternative explanations for thes model's uniform lailure.

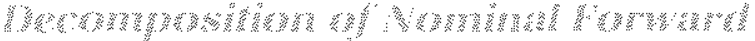 in when}

Aso repored in table 2 is the fistatisto for lesing whener decomposing the change in the rominal torware premium into innovations in its expected real and infuion components is statistualy watumed. rhe F-satistic is oblaned from the diference in the explantory power of equation 5 whth respect io equat

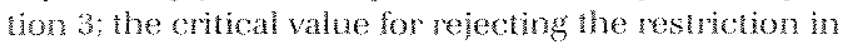
duaton 3 that $\beta, \beta$, in equation 5 me equall is 3.92 . Ony the velhetands resul rejeds the astriction.

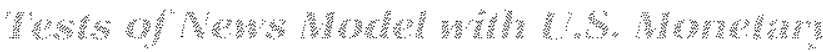

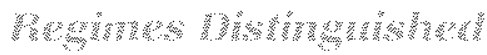

As discussed above, the L.S. monetary policy regime can be expected to affect he relationship betweon the dollar's exchangerates and U.S. foreign inerest difercntals. Thes, the statistical resuls reported in lable 2 may be invalid because they do not distinguish

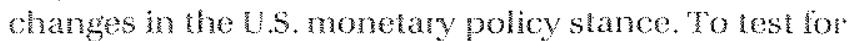
such policy regime efects, equations 3 and 5 , were stimated lo isolate the period of 4.5 . monetary agme Gave hageting, from October 197910 September 1982, will slope and intercept dummies.

Table 3 rports estmates of eqution 5 and the histatistics to test the eflect of monetary regine changes

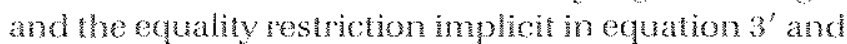
moved in equation ${ }^{\prime}$. The esthrmes present a substanial contrast to those in table 2 . Canada and laty

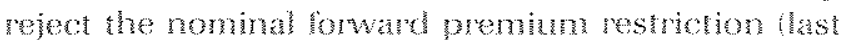


Table 2

Tests of News Model Using Change in Nominal Annualized Forward Premium on U.S. Dollar, October 1973-June 1985 (U.S. Monetary Regimes Not Distinguished)

\begin{tabular}{|c|c|c|c|c|c|c|}
\hline \multirow[b]{2}{*}{ Currency } & \multicolumn{2}{|c|}{ Coefficients } & \multicolumn{3}{|c|}{ Summary Statistics } & \multirow{2}{*}{$\frac{\text { Test }}{F^{2}}$} \\
\hline & Intercept & Afp & $\overline{\mathbf{R}}^{2}$ & DW & $\mathbf{F}$ & \\
\hline Canada & $\begin{array}{r}0.001 \\
(0.001)\end{array}$ & $\begin{array}{l}0,069 \\
(0.102)\end{array}$ & 0,004 & 216 & 0.455 & 2.059 \\
\hline France & $\begin{array}{r}-0.003 \\
(0.003)\end{array}$ & $\begin{array}{r}0.076 \\
(0.066)\end{array}$ & 0.002 & 2.04 & 1.347 & 2937 \\
\hline Gemany & $\begin{array}{l}0,004 \\
(0,003)\end{array}$ & $\begin{array}{r}0.146 \\
(0.188)\end{array}$ & 0.003 & 206 & 0.600 & 1.898 \\
\hline taly & $\begin{array}{r}0.002 \\
(0.002)\end{array}$ & $\begin{array}{r}0,016 \\
(0,027)\end{array}$ & -0005 & 186 & $\begin{array}{r}0.332 \\
\end{array}$ & 0.053 \\
\hline Japan & $\begin{array}{r}0.002 \\
(0.003)\end{array}$ & $\begin{array}{l}0.017 \\
(0.035)\end{array}$ & 0006 & 180 & 0.236 & 1.254 \\
\hline Netherlands & 0,005 & $\begin{array}{r}0031 \\
(0031)\end{array}$ & 0000 & 203 & 1.004 & $4164^{*}$ \\
\hline Switzenland & $\begin{array}{l}0,004 \\
(0,003)\end{array}$ & $\begin{array}{r}0011 \\
(0.79)\end{array}$ & -0.007 & 192 & 0.004 & 0.326 \\
\hline United Kingdom & $\begin{array}{r}-0.002 \\
(0.003)\end{array}$ & $\begin{array}{l}0006 \\
(0.123)\end{array}$ & $\because 0.007$ & 1.83 & 0.002 & 1888 \\
\hline
\end{tabular}

Standard enrors of estimated coefficients appear in parentheses.

F-stats to for testing the equality restriction on the coefficients of the change in the real and the inflation differentials (components of the change in the nominal forward premium), asterisk indicates rejection at 5 percent level.

column, F-test but, in contrast to table 2 , the Netherlands does not when the U.S. monetary regine shift is acconnted for. Considering the appropriate specification, equations $3^{\prime}$ or $5^{\prime}$, six of the eight equations are significant in terms of their overall fit ( $F$-statistics) at the 5 percent level, Fance is significant at the 6 percent levet, and seven of eight countries reject the restriction of stable coefficients across monetary regime changes at the 10 percent level or better. Ony Japan fails the ${ }^{r}$-test for the significance of the model.

In terms of the individual coefficients, six of the eight countries evidence a significant negative risk premium 10 perent or better during the U.S. monetary agsogate largeting period, while the intercept is unifomy nonsignificant during the other U.S. monetary policy regime, Oclober 1973-September 1979 and October 1982-Jine 1985. The impact of the diferent regimes is also notable in the slope maraction dummy. The coefficint on the change in the real forward promium is negative and significan for Canada, Germany, the Netherlands, switzedand and the Jnited Kingdom. For Germany, switzerland and the
United kingdom, this entails a switch from a positive and significant coefficient during the U.S. non-monetary targeting regime.

Thus, for each of the seven curencies for which the market efficiency criteria are met, the U.S. monetary policy regine has a signiticant tfect on the erors in the forwand ate forecasts. More specifically, two generatitions can be advanced based on the results in lable 3 . First, the greater interest rate volatility during U.S. monetary aggregate largeting shows up in a significant risk premium lending to sirengthen the dollar against six of the eight eurrencies. Second, given the failure to rejed the nominal foward preminm restriction of equation $3^{\prime}$, the negative significance of the slope dumny implies that the interest differential news was primarily interpreted as an increase in the inflation differential during U.S. non-monetary agsegate targeting periods and as an increase in real inter" est defferentials during U.S. monetary aggregate targeting In other words, the dollar appreciated along with unantipated increases in the forward premium dur ing Otober 1979 to Seplember 1982, bul depreciated 


\section{Table 3}

\section{Tests of News Model Using Unrestricted Specification, October 1973-June 1985} (U.S. Monetary Regimes Distinguished)

\begin{tabular}{|c|c|c|c|c|c|c|c|c|c|c|c|}
\hline \multirow[b]{2}{*}{ Currency } & \multicolumn{6}{|c|}{ Coefticients $^{ \pm}$} & \multicolumn{3}{|c|}{ Summary Statistics } & \multicolumn{2}{|c|}{ Tests } \\
\hline & Intercept & D: & $\Delta\left(r-r^{*}\right)$ & Dr & $\Delta\left(\pi-\pi^{*}\right)$ & $\mathbf{D}_{\pi^{2}}$ & $\overline{\mathbf{R}}^{2}$ & DW & $F$ & $\mathbf{F}^{3}$ & $\mathrm{~F}^{4}$ \\
\hline Canada & $\begin{array}{r}0.002 \\
(0.001)\end{array}$ & $\begin{array}{r}0.000 \\
(0.003)\end{array}$ & $\begin{array}{c}0.299 \\
(0.188)\end{array}$ & $\begin{array}{c}-0.436 \\
(0.223)+\end{array}$ & $\begin{array}{c}0.343 \\
(0.209)+\end{array}$ & $\begin{array}{l}-0.776 \\
(0.253)^{\star}\end{array}$ & 0.056 & 2.19 & $2.728^{*}$ & $3.658^{*}$ & $4.027^{*}$ \\
\hline France & $\begin{array}{c}0.001 \\
(0.003)\end{array}$ & $\begin{array}{c}-0.015 \\
(0.006)^{\star}\end{array}$ & $\begin{array}{c}0.023 \\
(0.105)\end{array}$ & $\begin{array}{c}-0.077 \\
(0.135)\end{array}$ & $\begin{array}{c}0.368 \\
(0.193)+\end{array}$ & $\begin{array}{c}0.211 \\
(0.282)\end{array}$ & 0.045 & 2.12 & $2.297^{*}$ & $2.352+$ & 2.133 \\
\hline Germany & $\begin{array}{r}0.0001 \\
(0.003)\end{array}$ & $\begin{array}{c}-0.014 \\
(0.006)^{*}\end{array}$ & $\begin{array}{c}0.540 \\
(0.299)^{*}\end{array}$ & $\begin{array}{l}-1.137 \\
(0.382)^{*}\end{array}$ & $\begin{array}{c}-0.311 \\
(0.395)\end{array}$ & $\begin{array}{c}-0.980 \\
(0.511)+\end{array}$ & 0.081 & 2.10 & $3.445^{* *}$ & $4.837^{* *}$ & 0.605 \\
\hline ltaly & $\begin{array}{l}0.000 \\
(0.003)\end{array}$ & $\begin{array}{c}0.011 \\
(0,006)+\end{array}$ & $\begin{array}{c}0.012 \\
(0.033)\end{array}$ & $\begin{array}{c}-0.067 \\
(0.056)\end{array}$ & $\begin{array}{c}0.139 \\
(0.100)\end{array}$ & $\begin{array}{c}0.568 \\
(0.181)^{k}\end{array}$ & 0.059 & 1.92 & $2.731^{*}$ & $4.415^{\star \star}$ & $3.990^{*}$ \\
\hline Japan & $\begin{array}{r}0.001 \\
(0.003)\end{array}$ & $\begin{array}{c}-0.012 \\
(0.006)+\end{array}$ & $\begin{array}{r}0.029 \\
(0.044)\end{array}$ & $\begin{array}{c}0.255 \\
(0.200)\end{array}$ & $\begin{array}{c}0.163 \\
(0.124)\end{array}$ & $\begin{array}{c}0.434 \\
(0.292)\end{array}$ & 0.016 & 1.89 & 1.443 & 1.899 & 1.093 \\
\hline Netherlands & $\begin{array}{r}0.001 \\
(0.003)\end{array}$ & $\begin{array}{c}0.013 \\
(0.006)^{*}\end{array}$ & $\begin{array}{c}0.047 \\
(0.029)\end{array}$ & $\begin{array}{c}-0.816 \\
(0.243)^{*}\end{array}$ & $\begin{array}{l}0.280 \\
(0.161)+\end{array}$ & $\begin{array}{r}-0.536 \\
(0.343)\end{array}$ & 0.107 & 2.06 & $4.324^{* *}$ & $5.313^{\star \star}$ & 2.098 \\
\hline Switzeriand & $\begin{array}{c}0.001 \\
(0.004)\end{array}$ & $\begin{array}{l}-0.018 \\
(0.007)^{*}\end{array}$ & $\begin{array}{c}0.433 \\
(0.218)^{*}\end{array}$ & $\begin{array}{c}1.217 \\
(0.356)^{*}\end{array}$ & $\begin{array}{c}0.506 \\
(0.263)+\end{array}$ & $\begin{array}{c}1.191 \\
(0.437)^{\star}\end{array}$ & 0.088 & 2,03 & $3.688^{\star \star}$ & $6.025^{\star *}$ & 0.162 \\
\hline United Kingdom & $\begin{array}{r}0.001 \\
(0.003)\end{array}$ & $\begin{array}{r}-0.006 \\
(0.006)\end{array}$ & $\begin{array}{c}0.382 \\
(0.149)^{*}\end{array}$ & $\begin{array}{c}0.950 \\
(0.238)^{*}\end{array}$ & $\begin{array}{c}0.319 \\
(0.180)+\end{array}$ & $\begin{array}{c}1.087 \\
(0.296)^{*}\end{array}$ & 0.097 & 1.79 & $3.979^{* \star}$ & $5.933^{\star *}$ & 1.052 \\
\hline
\end{tabular}

Standard errors of estinated coefficients appear in parentheses; asterisk indicates significance at 5 percent level and plus sign indicates significance at 10 percent level:

2DI, Dr and Dis equal 1.0 during period of U.S. monetary-target policy regime, October 1979-September 1982 and zero otherwise.

3F-stafistic for testing restriction that coefficients are stable across different monetary regimes; double asterisk indicates rejection at 1 percent level, asierisk indicates rejection at 5 percent level, and plus indicates rejection at 10 percent level.

${ }^{4} \mathrm{~F}$-statistic for testing the equality restriction on the coefficients of the change in the real and the inflation differentials (components of the change in the nominal forward premium); asterisk indicates rejection at 5 percent level, plus indicates rejection at 10 percent level.

wilh such news during the rest of the floating rate period. This is consistent with Frenkel's 1981 at results for 1973-79. Finally, the Dubin-Watson statistics in table 3 do not indicate serial corelation in the residuals, consistent with the maintaned hypothesis of market efficiency.

There remain two puzding results: 11 The estimated coefficients of the change in the intlation differential during the monetary regine are generally negalive, reluting the hypothesis embodied in equation 5 ; this negarive cofficient is signifuan at the 10 percent level or beter in five countries. (2) Moreover, the decomposition of the rominal interest diferential is significan only for Canada and ltaly. This imetevance of the distinction between real and nominal interest dimerentials may simply be a confmmation of fama's (1984) assertion that, with risk aversion or withon ppp, the Fisher equation does not hold isee foomolo 9 !
Indeed, for six of the eight turencies, the F-test does not reject the implicit restriction of equality of changes in the nominal interest diferential's two components displayed in table 3 .

\section{W

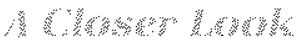

The nggalive coefficient on the infation differential duming the $1979-82$ monetary regime is both ponasive and puzzling. Two possible explanations are worth considering. Fist, the one-month horizon of the estimated, anticipated $C P$ inflation rates used in estimating equation $5^{\prime}$ may be too short, of the estimated expected inflation series simply may be bat proxies.

Second, the maket mat have detemined that the U.S. monetary anthorty and the administration were commited to lowering the U.S. intlation mate Conse- 
Guenty, a shothem increase in the U.s. expected infation tate would lead maket participants to expect a tighoning of monetary growth. ${ }^{1+}$ If $\mathrm{so}$, a shontem increase in $U$. S. inflation would lead to increases in the U.S. mal interest rate as the maket anticipaled the monetary authority seation. This explanation, wonsistent wh research by Conell (1982), thas not been tested here, but it is consistent with the decomposition of changes in the nominal interest differential generally not increasing ane explanatory power of the culation for six of the eight currencies.

\section{Mring}

We have tested the efliciency of forward exchange markets for the dollar agatinst eight major currencies during the foating period. The regression estmates clearly demonstrate that failing to account lor changes in the policy procedures of the US. monetary atthor ity entats misspecification. Monetary regime changes alter the risk premia that market panticipants require on forward contracts and affect the direction of erross implied by noninal and real news, that is, unforeseen events oceuring between the time of contract and its maturity. The implications of the slandard model of exchange rate behrvior were substantiated for nominal news under a monotary targel regime, but ins implication for inflaton diferentals was refued. While a closer modeling of the policy procedure may explain this rejection, it remains a prominent puzzle in this study. Nonetheless, one interpmetaton of these rasulits is that manke participants regarded the U.S. monetary policy regime of $1979-82$ as antintationary, if this is correct, follows that credible goals of monetary policy may be as signifhant for market participans as the mechanical detals of that policy's execution.

\footnotetext{
14The U.S. CPl intlation rale was 13.3 percent in $1979,12.4$ percent in $1980,8.9$ percent in 1981 and 3.9 percent in 1982 . There is also some support for this view in the impact of lagged reserve accounting during the monetary targeting period. As Kautman (1982) notes, this results in more volatility of both money and interest rates since a decision to maintain a target growth path when the money supply has exceeded the path requires a subsequent reduction of reserve growth. Since banks already will have increased their required reserves, real rates witl vary with the money supply errors and, perhaps, shortun inilation expectations.

icomell (1982) finds that unexpected monetary supply increases are correlated with an appreciation in the dollar, not the depreciation that an anticipated simple lnk with increased inflation would imply. Comell suggests that the explanation is an anticipated policy reacthon, a fighening of the money supply growth tate.
}

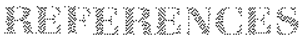

Baille, Richard T. Robert E. Lippens and Patrick C. McMahon. "Testing Rational Expectations and Etficiency in the Foreign Exchange Market," Econometrica (May 1983), p. 553-63.

Bomhot, Eduard, and Pleter Korteweg. "Exchange Rate Variability and Monetary Policy Under Rational Expectations," Joumal of Monetary Economics. 1983.

Casse: Gusiav. Money and Foreign Exchange After 1914 (New York: McMillan, 1922).

Connell, Bradford. "Money Supply Announcements, Interest Rates and Foreign Exchange," Joumal of International Money and Finance (August 1982), pp. 201-08.

Darby, Michael R. "Does Purchasing Power Parity Work?" Proceedings of Fitth West Coast Academic/Federal Reserve Economic Research Conference, University of California-Los Angeles, National Bureau of Economic Research (December 1981).

Dooley, Michael P., ard Peter Isard. "Capital Controls, Political Risk and Deviations from Interest Rate Parity." Joumal of Political Economy (April 1980), pp. 370-84.

Dornbusch, Rudiger. "Expectations and Exchange Rate Dynamics," Joumal of Political Economy (December 1976), pp. $1161-$ 76.

Edwards, Sebastian. "Comment on Isard" Jacob A. Frenkel, in Exchange Rates in International Macroeconomics (University of Chicago Press, 1983).

. "Floating Exchange Rates, Expectations and New information," Joumal of Monetary Economics (May 1983b), pp. 32136.

Fama, Eugene F. "Forward and Spot Exchange Rates," Joumal of Monetary Economics (November 1984), pp. 320-38.

Frenkel, Jacob A. "Flexible Exchange Rates, Prices and The Role of "News": Lessons From the 1970s," Joumal of Political Economy (August 198 ta), pp. $665-705$.

"The Collapse of PPP in the 1970s," European Economic Review (1981b), pp. 145-65.

Gilbert, Alton. "Operating Procedures for Conducting Monetary Poltey," this Review (February 1985), pp. 13-21.

Fansen, Lars Peter and Robert J. Hodrick. "Forward Exchange Rates as Optimal Predictors of Future Spot Rates: An Econometric Analysis," Joumal of Political Economy (October 1980), pp. 82953 .

"Risk Averse Speculation in the Forward Foreign Exchange Markef: An Econometric Analysis of Linear Models" in Frenkel, Ed. Exchange Rates in International Macroeconomics (University of Chicago Press, 1983 ).

Hodick, Roberi ... and Sanjay Srivastava. "The Covariation of Risk Premiums and Expecied Future Spot Exchange Rates," Jounal of inemational Money and Finance (March 1986 Suppiement), pp. 5 23

Isard, Peter. "An Accounting Framework and Some Issues for Modelling How Exchange Rates Respond to News," in Jacob A. Fenkel, Exchange Rates in intemational Macroecononics (University of Chicago Press, 1983 ).

Jacobs, Rociney L. "The Eflect of Errors in Variables on Tests for a Risk Premium in Fonward Exchange Rates," Joumal of Finance Uune 1982 ), pp. $667-77$.

Johnson, Karen. "Foreign Experience with Targets for Monetary Growh," Federal Resene Bulletin (October 1983), pp. 745-54.

Kauman, George. "The Fed's Postoctober 1979 Technical Operaing Procedures Under agged Reserve Reguirements: Reduced 
Ability to Control Money," The Financial Review (November 1982), pp. $279-94$.

Lucas, Robet E., Jr. Eds, Kar: Brunner and Alan Melzer, 1974, "Econometric Policy Evaluation: A Critique," The Phillos Cuve and Labor Markets, Camegie-Rochester Conterence on Public Pollcy, Vol. 1, pp. 19-46.

Mussa, Michael L. "Empincal Regularties in the Behavior of Exchange Fates and Theories of the Foreign Exchange Market." Vol. 11 Camegie-Rochester Conterence Series on Public Policy, 1979.
Rasche, Robert H. "Interest Rate Volatily and Alternatyo Monetary Control Procedures," Economic Feview, Federal Feserve Bank of San trancisco (Summer 1985), pp. 46-63.

Boley, Vance. "The Response of Shot-Term hierest Rates to Weeky Money Announcements:" Journal of Money, Credit and Banking (August 1983), pp. 344-54.

Wood, John, and Norma L. Wood. Financial Markets (Haroourt Brace Jovanovich, inc. New Yok 1985 